\title{
BEYOND THE INCIDENCE OF \\ TRAINING: EVIDENCE FROM A \\ NATIONAL EMPLOYERS SURVEY
}

\author{
Lisa M. Lynch
}

Sandra E. Black

Working Paper No. 5231 


\author{
BEYOND THE INCIDENCE OF \\ TRAINING: EVIDENCE FROM A \\ NATIONAL EMPLOYERS SURVEY
}

Lisa M. Lynch

Sandra E. Black

Working Paper No. 5231

\author{
NATIONAL BUREAU OF ECONOMIC RESEARCH \\ 1050 Massachusetts Avenue \\ Cambridge, MA 02138 \\ August 1995
}

The work reported herein was supported under the Education Research and Development Center program, agreement number R117Q00011-91, CFDA 84.117Q, as administered by the Office of Educational Research and Improvement, U.S. Department of Education. This funding was administered through the National Center on the Educational Quality of the Workforce (EQW), University of Pennsylvania. The findings and opinions expressed in this report do not reflect the position or policies of OERI, the U.S. Department of Education, or the Bureau of the Census. The authors would like to thank Steve Rudolph, Arnie Reznek, and Joyce Cooper for substantial assistance on the construction of the data set, Barbara Gelhard and Dan Shapiro of EQW for research assistance, and Fabio Schiantarelli for helpful comments on the paper. This paper is part of NBER's research program in Labor Studies. Any opinions expressed are those of the authors and not those of the National Bureau of Economic Research.

() 1995 by Lisa M. Lynch and Sandra E. Black. All rights reserved. Short sections of text, not to exceed two paragraphs, may be quoted without explicit permission provided that full credit, including $\odot$ notice, is given to the source. 


\title{
BEYOND THE INCIDENCE OF \\ TRAINING: EVIDENCE FROM A \\ NATIONAL EMPLOYERS SURVEY
}

\begin{abstract}
This paper seeks to provide new insight into how school and post school training investments are linked to employer workplace practices and outcomes using a unique nationally representative survey of establishments in the U.S., the Educational Quality of the Workforce National Employers Survey (EQW-NES). We go beyond simply measuring the incidence of formal or informal training to examine the determinants of the types employers invest in, the relationship between formal school and employer provided training, who is receiving training, the links between investments in physical and human capital, and the impact that human capital investments have on the productivity of establishments. We find that the smallest employers are much less likely to provide formal training programs than employers from larger establishments. Regardless of size, those employers who have adapted some of the practices associated with what have been called 'high performance work systems' are more likely to have formal training programs. Employers who have made large investments in physical capital or who have hired workers with higher average education are also more likely to invest in formal training and to train a higher proportion of their workers, especially in the manufacturing sector. There are significant and positive effects on establishment productivity associated with investments in human capital. Those employers who hire better educated workers have appreciably higher productivity. The impact of employer provided training differs according to the nature, timing and location of the employer investments.
\end{abstract}

Lisa M. Lynch

Fletcher School of Law \& Diplomacy

Tufts University

Medford, MA 02155

and NBER
Sandra E. Black

Department of Economics

Harvard University

Cambridge, MA 02138 


\section{Introduction}

Increasing international competition, new technologies such as information technology, and changing work organization have contributed to a growing debate in the United States on the ways in which workers accumulate skills relevant for the rapidly evolving workplace. Historically, the U.S. has relied on a system of formal school-based learning combined with informal learning on-the-job to supply the necessary skills for the workplace. Although this system seemed to be able to adequately supply the human capital needs of most firms through the 1960 's, there is a growing concern that this system is not sufficient to meet the current needs of employers. In particular, now more than ever the need to acquire new skills does not stop once individuals leave school, instead, workers need to be taught by schools to 'learn how to learn' so that they can continue to develop new skills throughout their working lives. In addition, once in the workplace, workers need to find some way to obtain skills (such as those associated with information technology or new work practices such as Total Quality Management, TQM) that do not seem to be easily obtained informally on-the-job. In the past, much of the research on the impact of human capital accumulation has focused on the impact of pre-employment investments in human capital (i.e. schooling) on subsequent labor market experience. This paper also attempts to provide new insight into the post school human capital investment experience and how school and post school human capital investments are linked to employers workplace practices and outcomes using a unique nationally representative survey of establishments in the U.S., the Educational Quality of the Workforce National Employers Survey (EQW-NES).

Before examining evidence from this new survey of employers, it is useful to put the 
discussion on investments in human capital into some perspective. Annual investments in human capital in the U.S. are quite large. For example, during 1990 over $\$ 377$ billion (in 1989 dollars) was spent on K-12 and public and private higher education (U.S. Dept. of Education, 1993). At the same time, Carnevale (1990) estimated that at least $\$ 32$ billion in 1986 was spent annually on firm provided formal training in the U.S. However, constructing precise estimates on the actual annual training expenditures paid out by firms turns out to be rather difficult to do. For example, the training expenditures referred to by Carnevale have not been updated since 1986, and other researchers have argued that annual expenditures on formal training by firms could be as high as $\$ 148$ billion or even double this figure if informal training costs are included (see Mincer (1988) and Lynch (1995)). As a comparison, total non-farm expenditures on new plant and equipment in the U.S. in 1990 were slightly over $\$ 590$ billion. So, there are large investments made annually in both human and physical capital.

The problem in the current policy debate on workforce preparedness is that these aggregate measures of expenditures on education and training do not reveal much about which types of training employers are choosing to invest in, the relationship between formal schooling and employer provided training, who is receiving training, the links between investments in physical and human capital, and the impact that human capital investments have on productivity of establishments. Employers are continually faced with the decision of whether to make additional investments in training within their establishments or to purchase skills from the outside. Employers' investment decisions will also be influenced in part by the characteristics of the workers they employ. Employees who are perceived to have higher turnover rates are less likely to receive employer provided training. At the same time, employees who have 
already shown an aptitude to learn new skills by having completed more years of schooling may then be more likely to receive additional human capital investments provided by an employer. How employer investments in human capital are related to investments in physical capital is not clear a priori. On the one hand, some employers may view investments in physical capital as a way to substitute away from skilled labor. On the other hand, some may view investments in human capital as complements to investments in new physical capital. Finally, investments in human capital are costly and employers need to assess the impact of their investment strategies on productivity.

The EQW-NES allows us to start to examine these kinds of issues and move beyond simply measuring the incidence of post school training. This paper begins by summarizing the characteristics of employer provided training as found in the EQW-NES. It then goes on to examine the determinants of the probability of employer provided formal training programs, the determinants of offering different types of training programs (e.g. team work, computer skills training, etc...), and the factors linked with the proportion of workers trained in an establishment. In particular, the analysis focuses on how post school training investments by employers are related to their investments in physical capital and the level of education of workers. The paper then develops a simple model of the impact of human capital investments on establishment productivity and concludes with a summary of results and an outline of future research.

\section{The Survey}

The EQW National Employers Survey (designed by Lisa Lynch in collaboration with 
EQW Co-Directors Robert Zemsky and Peter Cappelli) was administered by the U.S. Bureau of the Census as a telephone survey in August and September 1994 to a nationally representative sample of private establishments with more than 20 employees. The survey represents a unique source of information on how employers recruit workers, organize work, invest in physical capital, and utilize education and training investments. The survey goes one step beyond many previous surveys of workplace practices by collecting information that will allow us to examine the impact that all of these factors have on the productivity of establishments and the wages of workers. In addition, the survey is structured to provide information on all categories of incumbent workers, not just new hires or those in core occupations.

The survey oversampled establishments in the manufacturing sector and establishments with over 100 employees. Public sector employees, not-for-profit institutions, and corporate headquarters were excluded from the sample. Although the survey excluded establishments with less than 20 employees (which represent approximately 85 percent of all establishments in the U.S.) the sampling frame represents establishments that employ approximately 75 percent of all workers. This is because while most establishments are small (less than 5 employees), most workers are employed in larger establishments. Since the focus of our research was on the intersection between employer practices and employees' human capital experiences, we decided to concentrate on those establishment employing the most employees. The target respondent in the manufacturing sector was the plant manager and in the non-manufacturing sector was the local business site manager. However, the survey was designed to allow for multiple respondents so that information could be obtained from establishments that kept financial information such as the book value of capital or the cost of goods and materials used in 
production at a separate finance office (typically at corporate headquarters for multiestablishment enterprises). Computer Assisted Telephone Interviewing (CATI) was used to administer each survey, which took approximately 28 minutes to complete.

The sampling frame for the survey was the Bureau of the Census SSEL file, one of the most comprehensive and up-to-date listings of establishments in the United States. Of the 4,633 eligible establishments who were contacted by Census, 1,275 refused to participate in the survey. This represents a 72 percent response rate, which is substantially higher than many similar establishment surveys ${ }^{1}$. The usual reason given by employers on why they would not participate in the survey was that they did not participate in voluntary surveys, or were too busy to participate. Probit analysis (available from the authors upon request) of the characteristics of nonrespondents indicates that there was no significant pattern at the two digit industry level in the likelihood of participating in the survey. The only businesses more likely not to participate were manufacturing establishments with more than 1000 employees. $^{2}$ Of the 3,358 establishments who participated in the survey not all respondents completed all parts of the survey by the interview cutoff date of October 1,1994 . The final number of surveys in which all parts of the survey were completed was 1,621 establishments in the manufacturing sector and 1,324 establishments in the non-manufacturing sector. This represents a 64 percent overall 'completed' survey response rate. The results presented in the following sections refer to this final sample of 2,945 establishments (see Appendix A for more details on the response rates, Appendix B for the distribution of establishments by industry and Appendix C for the distribution of establishments by employer size, weighted and unweighted). 


\section{The Incidence and Distribution of Training}

Table 1 reports the incidence of both formal and informal training by establishments size for the weighted sample of establishments. It is clear that most establishments ( $81 \%)$ offer some type of formal training. Not only do a high proportion of employers provide formal training but over 57 percent report that since 1990 the amount of formal training has increased, 41 percent report no change in the amount of formal training, and only $2 \%$ of employers report decreased amounts of formal training over this same time period. There is some variation in the incidence of training by establishment size, with smaller establishments (less than 100 employees) much less likely to offer formal training than the largest establishments (over 1000 employees). So, the incidence of training is high and has been growing through the 1990 s for the majority of employers. Formal training in this survey was defined as structured training that was offered at the establishment or at another location, and could occur during working hours or at other times. Structured training included all types of training activities that had a pre-defined objective. Examples of structured or formal training included seminars, lectures, workshops, audio-visual presentations, apprenticeships, and structured on-the-job learning. In addition, the respondents were asked about the incidence of unstructured or informal training. This was defined as training where employees learn by observing others doing the job, or are shown how to do a job in an informal one-on-one situation by supervisors, co-workers or others. Virtually every establishment in the survey reported providing this type of training. Therefore, variation in the simple measure of the incidence of informal training will not get us very far in understanding differences in training practices across employers.

Table 2 reports the incidence of formal training by industry. Although the overall 
incidence of formal training is quite high, there is considerable variation by industry. For example, in the manufacturing sector, only 61 percent of establishments in the textile and apparel sector offer some type of formal training program compared to over 87 percent of establishments in the chemical, petroleum, and primary metals sectors. In non-manufacturing, over $95 \%$ of all establishments in communication, utilities, finance, and insurance offer formal training programs, while only $70 \%$ of establishments in transportation services and wholesale trade offer formal training programs. Overall, the incidence of formal training programs appears to be higher in the non-manufacturing than manufacturing sector.

These findings are similar to those reported by the Bureau of Labor Statistics in a recent survey of approximately 12,000 establishments conducted in January 1994. The BLS found that 71 percent of establishments offered formal training programs. The fact that the BLS reports an incidence level that is lower than that found in the EQW-NES is most likely due to the fact that the BLS sample also included employers with less than 20 employees. These employers are much less likely to offer formal training than those covered in the EQW-NES sample. However, if we compare the incidence of formal training for employers with more than 50 employees reported in the BLS survey with the EQW survey, the BLS number is a bit higher. This probably reflects different wording of the questions and the fact that the BLS survey was a mailed survey while the EQW-NES survey was conducted by telephone. Nevertheless, the general patterns of the incidence of training by employer size and industry are very similar across both surveys.

Since the EQW-NES has detailed information on establishment characteristics, worker characteristics, and workplace practices it is possible to see how all of these factors together 
affect the probability of an establishment providing formal training programs. Table 3 presents logit maximum likelihood estimates of the impact these variables have on the probability of an employer to provide any type of formal training program. The establishment characteristics include: number of employees ( 5 size classes with more than 1000 employees the omitted category), a dummy variable equal to one if the establishment is part of a multiple establishment enterprise or firm, dummy variables equal to one if employment at the establishment has gone up or down over the past three years, and twenty one 2-digit industry controls (the sectoral groupings shown in Table 2). Since the survey also collected information on the book value of the capital stock it is possible to include the capital/labor ratio to see if those employers with greater investments in physical capital are more or less likely to invest in the human capital of their employees.

Worker characteristics include: a dummy variable equal to 1 if the employer reported more than 25 percent of workers were less than fully proficient in their current job, an establishment average education level which was constructed by calculating the weighted average across five occupational categories of average years of education in each occupation ${ }^{3}$, the percent of employees working at the plant for less than 1 year, a dummy variable equal to 1 if the employer reported that the skills required to perform tasks at the plant had increased over the past three years, the percentage of non-managerial workers who used computers in their jobs, the percentage of employees who were minorities or female, a dummy variable equal to one if any part of the plant or business site was unionized, and the percentage distribution of employment by five occupational categories (managerial and professional workers is the omitted category). 
Finally, proxies for workplace practices include: dummy variables equal to 1 if the employer reported using benchmarking or total quality management, a dummy variable equal to 1 if the employer allowed job sharing, the percentage of workers rotated across jobs, the percentage of workers in self-managed teams, the number of organizational levels within the plant, and the number of employees per supervisor. Although the original sample size of completed interviews in the manufacturing sector was 2,945 businesses, the logit analysis uses a smaller sample of 890 manufacturing and 624 non-manufacturing establishments. This is because there are missing data on several of the explanatory variables, especially the book value of the capital stock.

As shown in Table 3, businesses that employ less than 50 workers in manufacturing and 100 employees in non-manufacturing are much less likely to provide formal training programs to their workers than other larger sized establishments. In addition, those establishments with a higher capital/labor ratio are more likely to provide formal training programs. The industries less likely to report employer provided formal training programs, everything else constant, include textile and apparel, construction, transportation services, wholesale and retail trade, insurance, hotels, and business services. None of the remaining establishment characteristics were significant.

Significant worker characteristics in the manufacturing sector include the average educational level of the establishment's employees, the percentage of women employees, a dummy variable on increased skills demand, and the proportion of workers who are production, technical, or clerical/sales workers. All of these factors raised the probability of providing formal training programs. In non-manufacturing, increasing skills demand raised the probability 
of providing formal training, while a higher percentage of minority employees was linked to a lower probability of providing formal training programs. The results shown in Table 3 provide some evidence on the complementarity of investments in education and employer provided training. Those establishments with more highly educated workers are also more likely to provided additional human capital to their employees. Although some studies using household data have found that the probability of women receiving formal training is lower than for men, Table 3 suggests the opposite result (in the manufacturing sector). Since female employment is relatively low in the manufacturing sector as a whole, employers that hire disproportionately more women may need to provide more training since this group of workers is less likely to have had as much work experience in this sector.

Employers who use benchmarking or have introduced TQM into their establishments are also more likely to provide formal training, everything else constant. Both TQM and benchmarking require workers to take on more responsibilities for quality control and problem solving. These skills are probably more difficult for workers to acquire informally, so employers need to develop formal training programs to meet these skill needs. With the exception of R\&D in the non-manufacturing sector, none of the remaining workplace practices has a significant impact on the probability of providing any type of formal training program.

In sum, most employers provide some type of formal training programs, although there is substantial variation by size and industry in the probability of providing formal training programs. In particular, even after controlling for a variety of worker and establishment characteristics, the smallest employers are much less likely to provide formal training programs. This may be because smaller employers face higher per unit costs in the provision of formal 
training due to high initial set up costs, or they may have more concerns about losing trained employees to competitors. However, the survey is unable to establish the reasons why smaller employers are less likely to provided training. Regardless of size, those employers who have adopted some of the characteristics of 'high performance work systems' (e.g. Total Quality Management, TQM or benchmarking) are much more likely to have formal training programs. In addition, employers who have made large investments in physical capital relative to the number of workers, or who have hired workers with higher average education are more likely to train workers within their establishments. This suggests that employer provided training is a complement rather than a substitute to investments in physical and human capital. There seems to be evidence of a virtuous circle of investment in human capital - employee investments in schooling are further augmented by employer investments in training. The complementarity between training and physical capital is also an important finding. Concerns in the U.S. about the replacement of skilled workers with high tech machines and low skilled workers do not seem well founded.

\section{Types of Training Programs Offered}

Since such a high percentage of employers report offering formal or informal training programs, measuring the incidence of training does little to provide insight into the heterogeneity of training experiences across employers. In fact, the raw incidence numbers suggest that there is little evidence of a 'problem' in the provision of post school training. Yet there seems to be a perception in both the public policy arena and the private sector that there is under-investment in training in the United States. If the incidence of training does not look low, perhaps 
examining different dimensions of training, such as the content of training programs offered by employers, may shed some light on the nature of the training 'problem' in the U.S. Figure 1 shows the percentage of establishments engaged in 11 different types of training programs. Over three quarters of all establishments report financing or providing new hire orientation, health and safety, and new methods or procedures training. Approximately two thirds offer cross training, sales and customer service training, and managerial and supervisory training. Over half of the employers provide computer skills training, teamwork training, or tuition reimbursement, while only slightly more than a quarter of employers offer literacy, numeracy, or basic education training.

However, as we saw in our examination of the incidence of training, there is even further variation in the types of training programs offered by industry. For example, over $80 \%$ of establishments in sectors such as utilities, finance, insurance, chemicals, and petroleum products report offering computer skills training. Yet only 30 percent of establishments in the retail sector offer this type of training. Literacy, numeracy and basic education training is offered by very few employers in the business service, retail, or construction sectors (less than 20\%), however, over $50 \%$ of employers in utilities, finance, insurance and primary metals offer this type of training. Over $75 \%$ of establishments in the utilities, finance, insurance, chemicals and petroleum products industries pay for or provide teamwork training and only $35 \%$ of employers in the construction industry offer this type of training.

Table 4 presents estimates on the probability that an employer would pay for or provide four different types of training programs - computer training, teamwork training, basic education, and sales and customer service training. ${ }^{4}$ The analysis is again purely descriptive 
and we group our explanatory variables into the same categories used in Table 3: establishment characteristics, worker characteristics, and workplace practices. We already have seen in Table 3 that smaller employers are less likely to offer formal training programs than larger employers and this applies to most training types as well. This effect appears to be modified somewhat if the small establishment is part of a multi-establishment firm. In this case the establishment is more likely to provide formal training programs. This may be due to the fact that multiestablishment enterprises can lower the fixed costs of training for their smaller locations by spreading these costs over a number of establishments. The only type of training program for which there is no significant size effect is sales and customer service training. There is considerable variation in the impact of industry on the probability of offering different training types. Not surprisingly, establishments in the retail and hotel sectors are much more likely to provide sales and customer service training than establishments in any other industry. At the same time, there is no significant variation by industry in the probability of offering teamwork training, and there are no significant and positive industry effects for the probability of offering basic education. For computer training, the sectors including transportation services, retail, hotels, business services and health services are all less likely to be providing this type of training. However, those establishments in the chemical and petroleum products or utilities sector are significantly more likely to offer computer training, everything else constant.

Under the category of worker characteristics, we find that higher average educational level of workers at an establishment is positively linked to the provision of computer and teamwork training. At the same time, higher employee turnover tends to lower the probability of providing most types of training programs. The higher the percentage of minority workers 
at an establishment the lower the probability of providing computer training, while a greater the proportion of women employees appears positively related to the provision of sales and customer service training. Finally, the greater the proportion of technical workers in an establishment, the more likely the establishment is to be providing teamwork training.

New workplace practices associated with high performance work systems such as TQM and benchmarking seem to be linked with more general types of training programs such as computer training, teamwork training, and basic education. Finally, those employers who report that they have increased training over the past three years seem to be offering more of all types of training, rather than any single type of training program.

In sum, most employers are likely to provide specific training such as new hire orientation, health and safety and new methods or procedures training than numeracy, literacy and basic education. The type of training program offered varies considerably by employer size and industry. When we estimate a descriptive logit on the probability of offering each of four different types of training programs we see that smaller employers are less likely to offer computer, teamwork, or basic education training. In addition, average educational level and new workplace practices are positively related to higher skill development such as computer and teamwork training.

\section{Determinants of the Proportion of Workers Trained}

While the proportion of employers providing formal training programs is quite high in the U.S., recent surveys such as the 1991 Current Population Survey indicate that only $17 \%$ of workers report that they received formal training from their employer. So while most firms 
provide training, relatively few workers appear to be getting it. However, the reported rate of the proportion of workers involved in formal training programs in our survey is considerably higher (over $40 \%$ for the weighted sample) than the 17\% reported in the 1991 CPS.

There are several possible explanations for this higher figure in the EQW-NES. First, our survey is representative of establishments with 20 employees or more in the private sector. It is not a representative survey of the workforce as the CPS is. Since we know from Table 3 that smaller employers are less likely to provide formal training, excluding employers with less than 20 employees should mean that our estimates of the proportion of workers trained will be higher than what one would find for the economy as a whole. Second, a more recent survey of employer reported training by Barron, Berger and Black (1994) found that the proportion of newly hired permanent workers who received formal training to be around 28 percent. This number is probably an under-estimate of the total proportion of workers trained since newly hired workers are more likely to be in higher turnover positions with a lower probability of receiving training. Third, our survey took place 3 years later than the CPS study and during a period of economic expansion. Unfortunately, not having a nationally representative time series database on training makes it difficult to examine the impact of the business cycle and secular trends on the incidence of training. Fourth, the nature of the survey instrument (telephone, personal, mail), who the respondent was, and the reference period for the training questions could all lead to very different estimates of the proportion of workers trained. Finally, Barron, Berger and Black (1994) found that there is considerable measurement error between rates and hours of formal training reported by employers versus employees, with employees reporting lower rates of training than employers. We suspect that part of the problem may be 
that periods of training are labeled differently by workers and employers. For example, a supervisor who is assigned to work side-by-side with a new employee may view the time they spend with a new hire as training, whereas the employee views the fact that the supervisor is 'always hanging around' as monitoring, not training. All of this discussion suggests that our understanding of training and who receives it would be greatly enhanced by more matched employer-employee surveys and the development of a consistent time series on employer provided training.

Nevertheless, understanding the factors that are associated with the proportion of workers trained within an establishment may provide further insight into the nature of the training 'problem' in the United States. Table 6 presents Tobit maximum likelihood estimates of the determinants of the proportion of workers receiving formal training within each establishment. The explanatory variables are the same as those used in Tables 3 and 4. Table 6 allows us to see which employers not only provide formal training but also train 'deeply'. The determinants of the proportion of workers trained look somewhat similar to the determinants of the probability of offering formal training, especially in the manufacturing sector. Those establishments employing high performance work practices such as TQM, benchmarking, or self-managed teams are more likely to train a higher proportion of their workers. This result is not surprising since in order to successfully implement a high performance work system most, if not all, workers need to be trained. Those establishments in the manufacturing sector with a higher capital/labor ratio are also more likely to train a higher proportion of their workers, as are those establishments with more educated employees (although this latter effect is not quite significant at the 10 percent level for a two-tailed t-test). 
One of the major differences between this table and Table 3 are the coefficients on establishment size. Smaller establishments do not seem less likely to train a higher proportion of their workers, conditional on training at all. This is consistent with the existence of high fixed training costs. In addition, in the non-manufacturing sector, those establishments employing a higher proportion of office/clerical workers or sales/customer service or other front line workers train a much lower proportion of their employees. These occupations in the nonmanufacturing sector tend to be the jobs with the highest turnover rates. In sum, even though there is a very high incidence rate of formal training across employers, there are significant differences across employers in terms of who actually receives formal training from their employer.

\section{Other Dimensions of Training Practices}

In the EQW-NES over $60 \%$ of the formal training paid for by establishments uses inhouse rather than external training providers. However, for the forty percent of training that is provided by vendors outside of the workplace, there is a large variety in the sources of trainers used by employers. Table 5 provides a distribution of the percentage of establishments using different types of training providers for their formal training programs. Over 50 percent of employers report using equipment suppliers or buyers for part of their formal training programs. Other training providers include private consultants, private industry councils, technical/vocational institutions (both for profit and not-for-profit), community and junior colleges and four year colleges or universities. However, only 12 percent use other government funded training programs and even fewer $(5 \%)$ use unions. 
While the survey contained a question on the percentage of total annual labor costs spent on formal training programs, many employers in the survey answered this questions with, "Don't Know". For the employers who do answer the question on training costs, most report annual formal training costs less than 5 percent of total labor costs. ${ }^{5}$ But given the low response rate to this question (only 50 percent of employers report a value for this question) it makes it difficult to use this variable in any analysis. Although data in countries such as France and Australia on training costs of employers is well documented since they have used mandated employer training taxes, the EQW-NES seems to suggest that U.S. employers are not geared up to measure training costs at the moment. This is because there are no clear and commonly agreed upon accounting principles for determining training costs, especially indirect costs such as lost production. For example, many employers, as shown in Table 5, rely on outside equipment suppliers to provide their internal training. This generates one type of problem in quantifying training costs. If a business purchased a new photocopier machine and the vendor, as part of the purchase price, agreed to come on site and train operators for this machine, then the training 'cost' may well be hidden in the cost of the new capital investment. Collecting information on training expenditures without a common definition of what constitutes training expenditures is problematic.

An additional question employers had some difficulty with in the EQW-NES was the number of hours employees in different occupations spent in formal training. Because of the lower response rate to this question than to the question on the number of workers who had received training, we have not used hours of training in any of our analysis so far. However, for those employers who do report positive hours of training it is interesting to see that technical 
workers spend almost twice as much time in training as production or even managerial employees (102 hours versus 60 hours per year). This suggests that greater attention should be paid to distinguishing the training experience of technical workers from that of other production and non-production workers.

Finally, on average, 71 percent of formal training takes place during working hours. Interestingly, Barron Berger and Black (1994) found that approximately 75 percent of formal training took place on-site (presumably during working hours), and 25 percent occurred off-site. The percentage of time spent in formal tracing during working hours could be re-cast as time in formal on-the-job versus time in formal off-the-job training. Researchers, such as Bishop (1994) have found evidence that the returns to employer provided off-the-job training are much higher than the returns to on-the-job training. We will begin to explore this issue in the next section of this paper.

\section{The Impact of Human Capital Investments on Productivity}

There have been very few studies in the U.S. on the impact of employer provided training on productivity. Some of the few studies (e.g. Barron et. al. (1994) and Bishop (1994)) that do link training and productivity have used a subjective measure of productivity such as 'on a scale of 1-4 how has your productivity changed over the last year', or a measure of the productivity of the most recent hire relative to a fully trained worker, rather than using actual output or value added in order to construct measures of labor productivity or total factor productivity. The main problem with subjective measures of productivity is that these measures are not comparable across firms or even within firms over time. They also do not allow one 
to estimate rates of return to training versus other human resource practices.

Even given these caveats, there are some interesting findings associated with these subjective measures of productivity. Barron et. al. (1987) and Bishop (1994), use data from the 1982 Employment Opportunity Pilot Project survey and Bishop (1994) uses data from the National Federation of Independent Business survey to examine the impact of training in the first three months of employment on subjective measures of productivity for recent hires in establishments. In the EOPP survey of 659 establishments, training is divided into formal and informal training, with data collected on the duration/intensity of training, starting wages, starting productivity, current wages and current productivity. The survey included a 'productivity' measure where employers were asked to rate the productivity of the most recent hire at the start of their job and currently on a scale from 0-100 (where 100 equals the maximum productivity rating any employee in a defined position could attain). This is not a nationally representative sample of employers, and the questions refer to the most recent new hires and not all incumbent workers in the establishment. In addition, by focusing just on newly hired employees, the survey oversamples workers in high turnover jobs. We would expect a priori that these jobs would have less training attached to them.

The NFIB survey has a larger sample of 2,599 establishments (with a $25 \%$ response rate) than the EOPP survey, but it was designed to be very similar to the EOPP survey since it focuses on the employment experience of the most recent hire. In addition, the productivity measure used in this survey is similar to that in the EOPP survey. Bishop (1994) concludes using data from this survey that employer provided training raises this subjective productivity measure by almost 16 percent. 
Other studies such as Bartel (1989) have linked data from a survey of human resource management practices at the establishment level with firm level data from Compustat on productivity and financial performance. However, since most of the establishments in the survey used by Bartel were part of multiple establishment firms, there is a discrepancy in the unit of analysis of inputs and outcomes since the Compustat data refer to the firm as a whole not to specific establishments. This problem, along with a low overall response rate in the HRM survey used by Bartel (6 percent), limits the reliability of the productivity analysis. Nevertheless, Bartel finds evidence that returns to training investments increase productivity on the order of 16 percent. In a follow up study Bartel (1992) examines a small longitudinal panel of manufacturing firms and finds that it is lagged training investments as opposed to current investments that yield positive effects on current productivity.

One of the unique features of the EQW-NES is that it is possible to examine outcome measures such as productivity and wages along with various measures of training and other workplace practices for a large nationally representative sample of employers. The survey was designed to replicate the questions asked in the Annual Survey of Manufacturers, ASM, on the dollar value of sales, receipts or shipments, the book value of the capital stock, and the cost of materials (including energy) used in production during calendar year 1993. Given the survey design these variables can then be augmented with worker characteristics (such as education and training), other establishment characteristics (such as the age of the capital stock), and workplace practices (such as TQM, benchmarking, etc...) to estimate a much richer production function than has been possible before. In addition, since we have collected sales, materials and capital data specifically for the establishment we are not forced to match establishment level workplace 
practices with enterprise level sales information.

In Table 7 we present results from a standard Cobb Douglas production function where:

eq. 1) $\log \left(Y_{i}\right)=$ constant $+a^{\prime *} X_{i}+b^{*} \log K_{i}+c^{*} \log M_{i}+d^{*} \log L H_{i}+e^{*} \log L Q_{i}$

Output $Y_{i}$ is proxied by the dollar value of sales, receipts or shipments for calendar year 1993 for establishment $i$ denoted by $S_{i}, K_{i}$ is the 1993 book value of the capital stock, $M_{i}$ is the total cost of goods and services used in the production of 1993 sales including energy, $\mathrm{LH}_{\mathrm{i}}$ are total labor hours for 1993 , and $\mathrm{LQ}_{\mathrm{i}}$ is a measure of labor quality which we proxy with the average educational level of the establishment denoted by ED. The vector $\mathrm{X}_{\mathrm{i}}$ includes whether or not the establishment is part of a multi-establishment enterprise, the age distribution of the capital stock, total number of workers trained in 1990 and $1993^{6}$, the percent of formal training that occurs off-the-job, dummy variables for three specific types of training activities, the percentage of the full time workforce that has been employed at the establishment for less than 1 year, whether or not grades or communication skills are considered important for recruitment purposes, dummy variables for the use of TQM or benchmarking, a dummy variable equal to one if the establishment exports any sales of its principal product, a dummy variable equal to 1 if there is a R\&D center anywhere in the enterprise, controls for capacity utilization, and whether or not the establishment is unionized. Since the value of sales, capital stock and materials need to be deflated by the appropriate price deflators, we use dummy variables for the 2 digit industrial classification of the establishment to account for this in our cross section estimation. 
Columns 1 and 3 of Table 7 report results for this unrestricted Cobb Douglas production function separately for the manufacturing and non-manufacturing sectors. Columns 2 and 4 impose two restrictions on the Cobb Douglas specification given in equation one. The first restriction tests (in the spirit of Jorgenson and Griliches (1967)) whether or not the coefficients on labor quality (average education) and labor hours are equal. If this is the case, then we can consider the labor input to be adjusted for quality where the adjustment factor is proportional to the average educational level of the establishment. In other words, if $d=e$ in equation 1 , then the labor input can be re-written as the product of labor hours times average education as shown below in equation 2 . This restriction is accepted at the 1 percent level yielding a coefficient on quality adjusted labor of .48 in manufacturing and .63 in non-manufacturing ${ }^{7}$. We then test to see if the restriction of constant returns to scale is accepted by our data (i.e. $b+c+d=1$ ), which it is at the 1 percent level. ${ }^{8}$ The restricted production function can be written as:

eq. 2) $\log \left(S_{i} /\left(L_{i}{ }^{*} E D_{i}\right)=\right.$ constant $+a^{*} X_{i}+b^{*} \log \left(K_{i} /\left(L H_{i}^{*} E D_{i}\right)\right)+c^{*} \log \left(M_{i} /\left(L H_{i}^{*} E D_{i}\right)\right)$

As seen in Table 7, human capital is an important determinant of establishment productivity. The average educational level of the establishment has a positive and significant effect in both the manufacturing and non-manufacturing sectors. The estimated coefficient in the unrestricted Cobb Douglas model implies that a ten percent increase in average education (approximately one more year of school) will lead to a 8.5 percent increase in productivity in manufacturing and a 12.7 percent increase in non-manufacturing. In the restricted model presented in columns 2 and 4 of Table 7 the implied coefficient on education would suggest that 
for a ten percent increase in education, productivity would rise 4.9 percent in manufacturing and 5.9 percent in non-manufacturing. These values set the range of education's impact on productivity. Although the range is somewhat large, the impact of education on establishment productivity is substantial, especially in non-manufacturing. Since the non-manufacturing sector is expanding much more rapidly than manufacturing in the U.S., this result may shed some light on the finding that the college/high school wage gap has widened so dramatically over the 1980s.

Training has a more complex impact on the productivity of establishments. Unfortunately, we are only able to get measures of the number of workers involved in training at two points in time - 1990 and 1993. This means that we do not have a measure of the accumulated stock of training for all workers, instead we are only able to measure training done in two particular years. This means that our estimates of the impact of training are likely to underestimate the true returns. In addition, given our earlier findings of a complementarity between investments in training and the educational level of workers there may be problems of multicolinearity. We find that the number of workers trained, especially in 1993, has no apparent impact on productivity. In manufacturing, the number of workers trained at the two points in time is not statistically significant, although the point estimates suggest that current training lowers productivity while past training raises current productivity. This is very similar to what we see happening with the age of the capital stock in manufacturing. Capital equipment less than a year old lowers productivity (although not statistically significantly), while capital stock aged 1-4 years raises current productivity. This suggests some sort of adjustment story where initially there are adjusted costs associated with the introduction of new skills and capital into the workplace that is then followed by positive improvements in productivity. 
When we include other dimensions of training we see more compelling evidence on the impact of training on productivity. For manufacturing, the greater the proportion of time spent in formal off-the-job training, the higher the productivity. This may be due to two possible reasons. First, training workers outside working hours lowers the output loss associated with on-the-job training. Second, those employers that train their workers off-the-job may be investing in more advanced and time intensive skills development. Unfortunately, our survey does not allow us to explore this issue in more detail.

For non-manufacturing, the content of the training programs provided by employers seems to have an important impact on productivity. In particular, computer skills development has a significant and positive impact on establishment productivity, even controlling for industry. This finding is consistent with evidence presented in Krueger (1993) of higher wage premiums associated with workers who use computers on the job. This result suggests that it is not so much whether you train workers but rather what you train the workers in that affects establishment productivity.

Recruitment strategies of establishments also play an important role in their productivity. In non-manufacturing, those establishments who cite grades as an important priority in hiring also have higher productivity. In manufacturing, the use of communication skills as a priority criterion in hiring decisions is almost significant at conventional levels in raising productivity. Table 8 shows the ranking in importance by employers of different applicant characteristics for recruitment and selection. What is striking about this table is how low a priority for most employers an applicant's grades are. Yet the results in Table 7, at least for non-manufacturing, suggest that those employers who do focus on grades experience significantly higher productivity 
than their competitors.

Other interesting results that come out from Table 7 include the negative impact that high labor turnover has on productivity, especially for non-manufacturing. Although it is not news that turnover is high in non-manufacturing, what this table suggests is that establishments pay quite a high price for this turnover in terms of lower sales. In non-manufacturing, unionization has a positive and rather large effect on establishment productivity. At the same time the use of TQM or benchmarking does not seem to have any impact on current productivity of establishments, in spite of the fact that we found a significant link between these practices and the training practices of employers. One possible explanation of why these variables do not enter significantly is that we have not controlled for the timing of the introduction of these practices. If an employer has only just introduced these practices we would expect to see a delay in the impact of these practices on productivity, just as we saw in the introduction of new physical capital. In addition, crude measures of the incidence of TQM or benchmarking do not capture how these programs are actually being implemented. Perhaps what is most important is not the introduction of TQM but rather how it is introduced, when it was introduced and how it has been implemented. This issue has been examined in much more detail in Ichniowski et. al. (1993) where they use more detailed industry information obtained in personal interviews and find a significant affect on productivity of high performance work systems depending on how they were actually implemented. Therefore, future data collection efforts should focus on obtaining more information on the content, timing and implementation of programs such as employer provided training, and total quality management.

While the results in Table 7 highlight the importance of human capital, especially 
education and certain types of employer provided training for establishments' productivity, there are several limitations with these findings. First and foremost is the problem of endogeneity. The presence of unobserved establishment characteristics that are time invariant is likely to bias our estimated coefficients. Although we have a richer specification for the production function than most researchers, we may still not be capturing all establishment characteristics linked to productivity. Our estimated coefficients may also be affected by measurement error. If we had longitudinal data on the establishments in our survey we could try to address the first problem of unobserved heterogeneity using within estimators to control for time invariant unobserved employer characteristics. GMM estimation of the model in first differences would also allow us, in principle, to address the issue of measurement error. Longitudinal data on training inputs would also allow us to examine how the accumulation of training over time within a business affects current productivity. Finally, our results suggest that it is important to move beyond simple measures of the incidence of workplace practices such as training or TQM in order to understand how these type of workplace strategies/investments actually pay off for employers. We hope in future work to use longitudinal data from the Annual Survey of Manufacturers to address some of the endogeneity issues and to use a follow up survey of the EQW-NES sample to obtain richer information on how workplace practices change over time.

\section{Conclusions}

Both the EQW-NES and the recent BLS survey of establishments show quite clearly that most employers in the U.S. provide some type of formal training programs, although there is substantial variation by size and industry in the probability of providing formal training 
programs. In particular, even after controlling for a variety of worker and establishment characteristics, the smallest employers are much less likely to provide formal training programs than employers in larger establishments. Regardless of size, those employers who have adopted some of the practices associated with what have been called 'high performance work systems' are much more likely to have formal training programs. In addition, employers who have made large investments in physical capital relative to the number of workers or who have hired workers with higher average education are more likely to train workers within their establishments. This suggests that employer provided training is a complement rather than a substitute to investments in physical and human capital. In addition, there seems to be evidence of a virtuous circle in human capital investments. Employee investments in schooling are then augmented by employer investments in training. Virtually all employers use informal training, so variations in the incidence of informal training across employers does not go far in explaining differences across employers in training strategies.

The type of training program offered by businesses varies considerably by employer size and industry. When we estimate a descriptive logit on the probability of offering each of four different types of training programs we find that smaller employers are less likely to offer computer, teamwork, or basic education training. In addition, average educational level and new workplace practices are positively related to "higher" skill development such as computer and teamwork training.

While most employers offer some type of formal training program, there is substantial variation across employers in terms of how 'deeply' they train. The proportion of workers trained in the manufacturing sector is positively associated with investments in capital and the 
average educational level of the employees. In both manufacturing and non-manufacturing the occupational structure of the establishment, and the use of new work practices such as TQM affect the proportion of workers trained. In addition, smaller establishments are likely to train a higher proportion of their employees, conditional on training at all.

Finally, there are significantly positive effects on establishment productivity associated with investments in human capital. Those employers who hire better educated workers have appreciably higher productivity. This is true for both the manufacturing and non-manufacturing sectors. This result is consistent with the finding that there is a large wage premium associated with completing a college degree relative to a high school degree. In addition, those employers in the non-manufacturing sector who use a measure of educational quality (grades) in their recruitment of new production or front line workers experience higher productivity than their competitors. The impact of training investments by employers differs according to their nature, timing and location. Our results suggest that formal training outside working hours has a positive effect on productivity in manufacturing, while computer training raises the productivity of non-manufacturing establishments. 


\section{References}

Barron, J., Berger, M. and Black, D. 1994. "How well do we measure training?", mimeo, Purdue University.

Bartel, Ann. 1992. "Productivity Gains from the Implementation of Employee Training Programs". NBER working paper \# 3893.

1989. "Formal Employee Training Programs and Their Impact on Labor Productivity: Evidence from a Human Resource Survey". NBER working paper \# 3026 .

Bishop, John 1994. "The Impact of Previous Training on Productivity and Wages", in L. Lynch editor, Training and the Private Sector: International Comparisons, Chicago: University of Chicago Press.

Carnevale, Anthony, et. al. 1990. Training in America. San Francisco: Jossey-Bass.

Delany, John, David Lewin and Casey Ichniowski. (1989) "Human Resource Policies and Practices in American Firms", BLMR report no. 137. Washington, D.C.: U.S. Department of Labor.

Jorgenson, Dale and Griliches, Zvi (1967), "The Explanation of Productivity Change", Review of Economic Studies, 34, pp. 249-283.

Ichniowski, Casey, Shaw, Kathryn, Prennushi, G. (1993). "The Effect of Human Resource Management Practices on Productivity", working paper, Columbia University, July.

Knoke, David, Kalleberg, A, Marsden, P. and Spaeth, J. 1993, "Job Training in U.S. Organizations", mimeo, University of Minnesota.

Krueger, Alan (1993), "How Computers Have Changed the Wage Structure: Evidence from Micro Data, 1984-1989", Quarterly Journal of Economics, Feb. pp. 33-60.

Lawler, Edward, Susan Mohrman, and Gerald Ledford. (1992) Employee Involvement and Total Quality Management: Practices and Results in Fortune 1000 Companies. San Francisco: Jossey-Bass.

Lynch, Lisa M. (1995) "A Needs Analysis of Training Data: What do we want, what do we have, can we ever get it?" in Labor Statistics Measurement Issues, edited by J. Haltiwanger, M. Manser and R. Topel, NBER/University of Chicago Press, forthcoming. 
Mincer, Jacob. (1988) "Job Training, Wage Growth and Labor Turnover". NBER working paper \# 2690, August.

Osterman, Paul. (1994) "How Common is Workplace Transformation and Who Adopts It?", Industrial and Labor Relations Review, vol. 47, no. 2, January, pp. 173-187. 


\section{ENDNOTES}

1. For example, Delany, Lewin and Ichniowski (1989) had a response rate of $6.5 \%$, Lawler, Mohrman, and Ledford (1992) had a response rate of 32\%, the National Federation of Independent Business survey in 1987 had a 25\% response rate (see Bishop (1994) for a review of this survey), the Small Business Administration survey of establishments in 1992 conducted by Barron, Berger and Black had a $50 \%$ response rate, and the National Organization Survey (1991) of establishments had a 50\% response rate (see Knoke et. al. (1993)). Nationally representative surveys of establishments with response rates closer to the EQW-NES rate include the BLS 1994 Training Survey which had a response rate of $70 \%$ and a 1992 survey of 875 establishments with more than 50 employees conducted by the University of Massachusetts Center for Survey Research and described in Osterman (1994) which had a response rate of $65 \%$.

2. Since establishments with more that 1000 employees represent only a fraction of all establishments $(.1 \%)$, we believe that our results are not overly skewed by this underrepresentation.

3. The occupational categories used in the survey for the manufacturing sector included managerial and professional workers, supervisors, technical workers, clerical/office/sales workers, and production workers. Similar categories were used for the non-manufacturing sector except that the last two categories were clerical/office workers, and sales/customer service or other front line workers.

4. We have run similar logits on all the other types of training programs but only report these four types since they seemed quite representative of the range of possible offerings by employers.

5. This is similar to the mean value of percent of labor costs spent on recruitment, 4.6 percent.

6. We also have tried specifications in which training is entered as the proportion of workers trained but the reported results do not change.

7. We do not report the results for the equation estimated just imposing the restriction of the equality of coefficients on labor hours and labor quality for reasons of space. Although it appears at first glance in Table 7 that it would be difficult to accept the restriction that the coefficient on labor hours and education are the same, the standard error on education is relatively large, even though the coefficient is statistically significant in both columns 1 and 3 .

8. Most studies on the determinants of productivity of U.S. establishments using cross section data find constant returns to scale. One difference between our results and those of other studies is that the coefficient on materials is much lower than what has been found in other studies. We believe this is because respondents had much more difficulty answering this question in the telephone interview than the questions on sales, capital or labor. Therefore, there is significant measurement error for materials. In future work, subject to availability, we hope to use data 
from the Annual Survey of Manufacturers to correct the materials data for at least a subset of our observations. 
Table 1 Percentage of Establishments Offering Formal and Informal Training (weighted means)

\begin{tabular}{lll} 
Number of Employees & $\begin{array}{l}\text { Formal } \\
\text { Training }\end{array}$ & $\begin{array}{l}\text { Informal } \\
\text { Training }\end{array}$ \\
\cline { 2 - 2 } All & $81 \%$ & $97 \%$ \\
$20-49$ & $75 \%$ & $96 \%$ \\
$50-99$ & $82 \%$ & $99 \%$ \\
$100-249$ & $90 \%$ & $98 \%$ \\
$250-999$ & $90 \%$ & $99 \%$ \\
More than 1000 & $99 \%$ & $98 \%$
\end{tabular}


Table 2 Training Incidence of Establishments by Industry (weighted means)

Industry

\% with Formal Training

All

$81 \%$

Manufacturing Sector

Food and Tobacco

$75 \%$

Textile and Apparel

Lumber and Paper

$61 \%$

$76 \%$

$78 \%$

Printing and Publishing

$88 \%$

Chemicals and Petroleum

$87 \%$

Primary Metals

Fabricated metals

Industrial machinery, Electronic equip., and instruments

$72 \%$

Transportation equipment

All other manufacturing

$74 \%$

$77 \%$

$78 \%$

Non-Manufacturing Sector

Construction

$79 \%$

Transportation

$70 \%$

Communication

$94 \%$

Utilities

$100 \%$

Wholesale Trade

$71 \%$

Retail Trade

$83 \%$

Finance

$96 \%$

Insurance

$95 \%$

Hotels

$77 \%$

$79 \%$

Business Services

Health Services

$79 \%$ 
Table 3 Determinants of the Probability of Providing Formal Training Programs (Logit Maximum Likelihood estimates)

$\underline{\text { Manufacturing } \quad \text { Non-Manufacturing }}$

Variable Names

\begin{tabular}{|c|c|c|c|}
\hline \multicolumn{4}{|c|}{ Establishment Characteristics } \\
\hline 0.24 & $2.60 * *$ & 0.14 & $1.76^{*}$ \\
\hline-1.55 & $-2.06 * *$ & -2.03 & $-2.21 * *$ \\
\hline-0.99 & -1.36 & -1.96 & $-2.19 * *$ \\
\hline-0.99 & -1.41 & -1.22 & -1.37 \\
\hline-0.58 & -0.84 & -1.20 & -1.35 \\
\hline 0.02 & 0.09 & -0.09 & -0.27 \\
\hline 0.19 & 0.62 & 0.19 & 0.56 \\
\hline-0.32 & -0.94 & 0.39 & 0.90 \\
\hline \multicolumn{2}{|c|}{ yes } & ye & \\
\hline
\end{tabular}

Worker Characteristics

Low proficiency

Average Education

$\%$ Workers $<1$ yr

Skills demand up

$\%$ non-managerial workers

using computers

$\%$ minority

$\%$ women

$\%$ production workers

$\%$ supervisory workers

$\%$ technical workers

$\%$ clerical/sales workers

unionized
$-0.17$

0.42

$-0.01$

0.96

$-0.0005$

$-0.003$

0.01

0.04

0.03

0.04

0.05

0.41
$-0.58$

$1.86^{*}$

$-1.08$

$3.53 * *$

$-0.10$

$-0.674$

$1.79 *$

$2.40 * *$

0.87

$1.76^{*}$

$2.12 * *$

1.30
0.10

0.23

0.001

0.55

$-0.003$

$-0.01$

0.01

$-0.02$

$-0.04$

$-0.02$

$-0.03$

0.29
0.29

1.27

0.13

$1.77 *$

$-0.74$

$-2.53^{* *}$

1.37

$-1.09$

$-1.07$

$-0.74$

$-1.56$

0.68

Workplace Practices and Characteristics

\begin{abstract}
use benchmarks
use TQM

Have Jobsharing

$\%$ workers rotated

$\%$ in self managed teams

\# organizational levels

\# ees per supervisor
\end{abstract}

$\begin{array}{cc}0.79 & 2.22 * * \\ 1.70 & 5.42 * * \\ -0.23 & -0.76 \\ 0.004 & 0.95 \\ -0.005 & -0.92 \\ 0.04 & 0.45 \\ -0.0005 & -0.05\end{array}$

0.22

0.77

$-0.32$

$-0.002$

$-0.007$

$-0.04$

$-0.001$
0.56

$1.85^{*}$

$-1.00$

$-0.34$

$-1.16$

$-0.36$

$-0.14$ 
Table 3 cont.

$\begin{array}{lcccc}\text { R\&D } & 0.11 & 0.37 & 0.80 & 1.70 * \\ \text { Export } & 0.35 & 1.30 & 0.06 & 0.16 \\ \text { Birth year of establishment } & -0.002 & -0.32 & 0.01 & 1.42\end{array}$

Equation also includes a constant.

Number of obs $=$

Log Likelihood $=$

Pseudo R2 =
890

$-232.70$

0.3169
624

$-166.23$

0.2264

** denotes significance at the 5 percent level

* denotes significance at the 10 percent level 
Table 4 Determinants of Probability of Offering Training by Type (Probit Estimates) ( $\mathrm{t}$-test in parentheses, $\mathrm{N}=2166$ )

Variable Name

$\begin{array}{llll}\text { Computer } & \text { Teamwork } & \text { Basic } & \text { Sales and Customer } \\ \text { Training } & \text { Training } & \text { Education } & \underline{\text { Service }}\end{array}$

Establishment Characteristics

$\begin{array}{lcllc}20-49 \text { ees } & -1.38^{* *} & -1.31^{* *} & -0.85^{* *} & -0.31 \\ & (-4.76) & (-5.04) & (-4.05) & (-1.41) \\ 50-99 \text { ees } & -1.16^{* *} & -1.29^{* *} & -0.89^{* *} & -0.34 * \\ & (-4.14) & (-5.16) & (-4.45) & (-1.70) \\ 100-249 \text { ees } & -0.72^{* *} & -1.05^{* *} & -0.41^{* *} & -0.09 \\ & (-2.67) & (-4.38) & (-2.28) & (-0.47) \\ 250-999 \text { ees } & -0.38 & -0.82^{*} & -0.33^{* *} & -0.13 \\ & (-1.46) & (-3.56) & (-2.06) & (-0.76) \\ \text { Multi est. } & 0.35 * * & 0.30^{* *} & 0.29 * * & 0.16 \\ & (2.69) & (2.50) & (2.42) & (1.33) \\ \text { Employment up } & 0.31^{* *} & -0.04 & 0.07 & 0.17 \\ & (2.21) & (-0.28) & (0.58) & (1.30) \\ \text { Employment down } & 0.29 * & 0.12 & 0.23 * & -0.03 \\ & (1.71) & (0.80) & (1.64) & (-0.21)\end{array}$

Industry controls

yes

yes yes yes

Worker Characteristics

$\begin{array}{lcccc}\text { Low proficiency } & 0.18 & -0.09 & 0.26^{* *} & 0.06 \\ & (1.28) & (-0.69) & (2.36) & (0.50) \\ \text { Average Education } & 0.14^{*} & 0.17 * * & -0.03 & 0.09 \\ & (1.73) & (2.43) & (-0.50) & (1.28) \\ \text { \% Workers }<1 \text { yr } & -0.01 * * & -0.003 & -0.01 * * & 0.003 \\ & (-2.50) & (-0.75) & (-2.50) & (0.75) \\ \text { Skills demand up } & 0.58 * * & 0.56^{* *} & 0.37 * * & 0.36 * \\ & (4.46) & (5.09) & (3.08) & (3.00) \\ \text { \% non-managerial } & 0.01 * * & -0.0004 & 0.001 & 0.003^{*} \\ \text { workers using computers } & (5.00) & (-0.20) & (0.50) & (1.76) \\ \text { \% minority } & -0.01^{* *} & 0.001 & 0.001 & -0.0035^{*} \\ & (-5.00) & (0.50) & (0.50) & (-1.75) \\ \text { \% women } & 0.004 & 0.003 & 0.0005 & 0.009 * * \\ & (1.33) & (1.00) & (0.17) & (3.00) \\ \text { \% production workers } & -0.001 & 0.005 & 0.002 & -0.004 \\ & (-0.14) & (0.83) & (0.40) & (-0.66) \\ \text { \% supervisory workers } & 0.003 & 0.005 & 0.0008 & -0.003 \\ & (0.03) & (0.50) & (0.08) & (-0.30)\end{array}$


Table 4 continued

\begin{tabular}{lcccc} 
Variable Name & $\begin{array}{l}\text { Computer } \\
\text { Training }\end{array}$ & $\begin{array}{l}\text { Teamwork } \\
\text { Training }\end{array}$ & $\begin{array}{l}\text { Basic } \\
\text { Education }\end{array}$ & $\begin{array}{l}\text { Sales and Customer } \\
\text { Service }\end{array}$ \\
\cline { 1 - 2 } \% technical workers & 0.005 & $0.013^{*}$ & -0.0003 & -0.003 \\
& $(0.63)$ & $(1.86)$ & $(-0.05)$ & $(-0.50)$ \\
\% clerical/sales workers & 0.01 & -0.003 & -0.002 & $0.02 * *$ \\
& $(1.11)$ & $(-0.43)$ & $(-0.28)$ & $(2.50)$ \\
unionized & 0.10 & 0.16 & 0.01 & $-0.30^{* *}$ \\
& $(0.67)$ & $(1.14)$ & $(0.08)$ & $(-2.50)$
\end{tabular}

Workplace Practices and Characteristics

$\begin{array}{lcccc}\text { use benchmarks } & 0.30^{* *} & 0.45^{* *} & 0.37^{* *} & 0.11 \\ & (2.00) & (3.75) & (3.36) & (0.92) \\ \text { use TQM } & 0.47^{* *} & 1.16^{* *} & 0.53^{* *} & 0.25^{* *} \\ & (3.36) & (9.67) & (4.82) & (2.08) \\ \text { Have Jobsharing } & 0.09 & 0.0004 & 0.14 & 0.21^{*} \\ & (0.64) & (0.003) & (1.17) & (1.75) \\ \text { \% workers rotated } & -0.004^{* *} & 0.007^{* *} & 0.002 & -0.0008 \\ & (-2.00) & (3.50) & (1.00) & (-0.40) \\ \text { \% in self managed teams } & 0.002 & 0.01 * * & 0.003 & 0.0002 \\ & (0.67) & (3.33) & (1.50) & (0.10) \\ \text { \# organizational levels } & 0.06 & 0.03 & 0.08^{* *} & -0.01 \\ & (1.50) & (1.00) & (2.67) & (-0.33) \\ \text { \# ees per supervisor } & -0.003 & -0.0002 & 0.004^{* *} & -0.006^{* *} \\ & (-1.50) & (-0.10) & (2.00) & (-2.00) \\ \text { training increased over } & 0.74 * * & 0.96^{* *} & 0.60^{* *} & 0.57^{* *} \\ \text { past 3 years } & (5.69) & (8.00) & (4.84) & (4.63) \\ \text { training decreased over } & 0.59 & 0.45 & 0.652^{* *} & 0.42 \\ \text { past 3 years } & (1.38) & (1.32) & (2.10) & (1.31)\end{array}$

(Equations also include a constant term)

Log Likelihood $=\quad \begin{array}{llll}-878.08 & -1023.64 & -1232.35 & -1162.21\end{array}$

** denotes significance at the 5 percent level

* denotes significance at the 10 percent level 
Table 5 Percentage of Establishments Using Various Sources of Training (weighted)

Source

Equipment Suppliers or Buyers

Private consultants

Private Industry Councils or Other

Industry Association

Technical and Vocational Institutions

Community and Junior Colleges

Four-year Colleges or Universities

Other Government Funded Training Programs

Unions

\section{Percent of Establishments}

$50 \%$

$36 \%$

$34 \%$

$33 \%$

$30 \%$

$20 \%$

$12 \%$

$5 \%$ 
Manufacturing

Variable Names

Log [Capital/Labor]

20-49 ees

50-99 ees

100-249 ees

250-999 ees

Multi est.

Employment up

Employment down

Industry controls

Estimate t-test

Non-Manufacturing

Estimate $\quad \mathrm{t}$-test

Establishment Characteristics

\begin{tabular}{|c|c|c|c|}
\hline .03 & $2.81^{* *}$ & .001 & 0.14 \\
\hline .03 & 0.48 & .19 & $2.49 * *$ \\
\hline .11 & $1.81^{*}$ & .17 & $2.35 * *$ \\
\hline .06 & 1.12 & .06 & 0.81 \\
\hline .07 & 1.52 & .06 & 0.87 \\
\hline .09 & $2.75 * *$ & -.02 & -0.49 \\
\hline-.03 & -0.67 & -.06 & -1.40 \\
\hline-.07 & $-1.66 *$ & -.06 & -1.32 \\
\hline
\end{tabular}

Worker Characteristics

Low proficiency
Average Education
$\%$ Workers $<1 \mathrm{yr}$
Skills demand up
$\%$ non-managerial workers
using computers
$\%$ minority
$\%$ women
$\%$ production workers
$\%$ supervisory workers
$\%$ technical workers
$\%$ clerical/sales workers
unionized

.02

.04

$-.0002$

.13

.0002

$-.0002$

.002

.006

.01

.005

.003

$-.009$
0.67

1.60

$-0.15$

$3.93^{* *}$

0.36

$-0.31$

$2.31 * *$

$3.00 * *$

$2.65 * *$

$2.13 * *$

1.34

$-0.25$
.06

$-.005$

.001

.08

.0004

$-.0001$

.001

$-.004$

$-.004$

$-.0005$

$-.005$

.04
1.42

$-0.28$

1.26

$2.01 * *$

0.78

$-0.19$

1.19

$-2.17 * *$

$-1.17$

$-0.31$

$-2.48 * *$

0.82

Workplace Practices and Characteristics

$\begin{array}{llccc}\text { use benchmarks } & .15 & 4.44^{* *} & .004 & 0.11 \\ \text { use TQM } & .18 & 5.36^{* *} & .12 & 3.12 * \\ \text { Have Jobsharing } & -.04 & -1.23 & -.02 & -0.45 \\ \text { \% workers rotated } & .0005 & 0.86 & .001 & 0.87 \\ \text { \% in self managed teams } & .001 & 1.73 * & .00 & 0.06 \\ \text { \# organizational levels } & -.01 & -1.34 & -.004 & -0.40 \\ \text { \# ees per supervisor } & -.001 & -1.64 * & -.001 & -0.78\end{array}$


Table 6 cont.

$\begin{array}{lllll}\text { R\&D } & .02 & 0.58 & .10 & 2.27 * * \\ \text { export } & .05 & 1.38 & .30 & 0.73 \\ \text { Birth year of establishment } & .002 & 2.85 * * & .0002 & 0.23\end{array}$

Equations also include a constant.

Number of obs

890
(162 left censored)
-551.72
0.18
624

(98 left-censored) $-384.009$

0.15

** denotes significance at the 5 percent level

* denotes significance at the 10 percent level 
Table 7 Determinants of Log Sales (Cobb Douglas Production Function) (T-tests in parentheses)

$\underline{\text { Manufacturing }}$

Dependent Variable

Variable Name*

Constant

Log Capital

$\log (\mathrm{K} /$ Hours*ED)

Log Materials

$\log (\mathrm{M} /$ Hours*ED)

Log Hours

Multiple Est.

$\%$ Equip $<1$ yr.

\% Equip 1-4 yr. old

Log Average ed.

Log Trained 1993

Log Trained 1990

\% formal training outside

working hours

Computer training

Teamwork training

Supervisor Training

Grades Priority

in recruitment

Communication

priority in recruitment

$\log ($ Sales $) \quad \log ($ S/hours*ED $) \quad \log ($ Sales $) \quad \log ($ S/hours*ED $)$

-1.252
$(-0.659)$
$0.36 * *$
$(9.957)$

$0.26^{* *}$

(11.812)

$0.47^{* *}$

(12.45)

$0.13 * *$

(2.257)

$-0.003$

$(-1.331)$

$0.003 * *$

(2.153)

$0.86 * *$

(2.028)

$-0.12$

$(-1.294)$

0.09

(0.994)

0.002 **

(2.104)

0.05

(0.714)

0.07

(0.983)

$-0.03$

$(-0.336)$

$-0.08$

$(-1.226)$

0.09

(1.52)
$0.25 * *$

1.06**

(7.335)

(11.311)

$0.26 * *$

(11.84)

$0.12 * *$

(2.183)

$-0.003$

$(-1.288)$

$0.003 * *$

(2.178)

-

$-0.12$

(-1.356)

0.09

(1.030)

0.002 **

(2.171)

0.06

(0.780)

0.06

(0.933)

$-0.03$

$(-0.333)$

$-0.08$

$(-1.176)$

0.09

(1.607)
Non-Manufacturing

$\begin{array}{cc}- & 0.35 * * \\ 0.06 * * & (9.959) \\ (2.958) & - \\ - & 0.06 * * \\ & (2.971)\end{array}$

$0.628 *$

(10.948)

$-0.05$

$(-0.382)$

0.005

(1.249)

$-0.0003$

$(-0.155)$

1.29*

(1.793)

0.08

(0.39)

$-0.11$

$(-0.515)$

$-0.001$

$(-0.461)$

$0.26^{*}$

(1.895)

$-0.20$

$(-1.617)$

0.20

(1.392)

$0.27 *$

(1.655)

0.14

(0.962)
$0.946 * *$

(2.717)

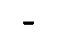

$0.35 * *$
$(9.959)$
-
$0.06 * *$
$(2.971)$

$-0.02$

$(-0.163)$

0.005

(1.327)

$-0.0004$

$(-0.181)$

0.07

(0.355)

$-0.09$

$(-0.425)$

$-0.001$

$(-0.520)$

$0.28 * *$

(2.108)

$-0.19$

(-1.556)

0.19

(1.322)

0.28 *

(1.741)

0.13

(0.930) 
Table 7 cont.

Manufacturing

Dependent Variable
Non-Manufacturing

$\log ($ Sales $) \quad \log ($ S/hours*ED $) \quad \log ($ Sales $) \quad \log \left(\right.$ S/hours $\left.{ }^{*} E D\right)$

\section{Variable Name*}

$\%$ Workers $<1$ yr.

$-0.003$

$-0.003^{*}$

$(-1.61)$

$(-1.692)$

Unionized

$-0.05$

$-0.06$

$(-0.793)$

$(-0.952)$

TQM

$-0.02$

$-0.03$

$(-0.347)$

$(-0.483)$

Benchmark

$$
0.03
$$

0.032

(0.539)

(0.558)

Above Capacity

$0.218^{* *}$

$0.21^{* *}$

(2.114)

(2.063)

Below Capacity

$-0.005$

0.001

Export

$(-0.10)$

0.10 *

$(-0.011)$

(1.845)

$0.10^{*}$

(1.796)

R\&D center

$-0.01$

$-0.01$

Birth year of Est.

$(-0.200)$

$(-0.133)$

0.001

0.001

(1.26)

(1.428)

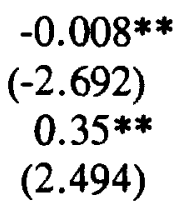

$-0.009 * *$

$(-2.875)$

0.01

$0.38^{* *}$

$-0.01$

(2.722)

$(-0.121)$

$-0.001$

0.08

$(-0.012)$

(0.621)

0.09

$0.37 *$

(0.721)

(1.816)

$0.36^{*}$

0.005

(1.796)

$(0.047)$

$-0.009$

$-0.05$

$(-0.076)$

$(-0.338)$

$-0.02$

$-0.05$

$(-0.157)$

$(-0.334)$

$-0.04$

0.0004

$(-0.265)$

(0.164)

0.0002

(0.087)

Industry Controls

yes

yes

yes

yes

$\mathrm{N}=$

821

821

Adjusted R Sq. =

0.8387

0.4331

525

525

0.6512

0.3814

** denotes significance at the 5 percent level

* denotes significance at the 10 percent level 
Table 8 Relative Ranking of Factors in Making Hiring Decisions

(scale of 1 to 5 where $1=$ not important or considered; $5=$ very important)

Applicant Characteristic

Applicant's Attitude

Applicant's communication skills

Previous work experience

Recommendations from current employees

Previous employer recommendation

Industry-based credentials

Years of completed schooling

Scores on tests administered as part

of the interview

Academic performance (grades)

Reputation of applicant's school

Teacher recommendations
Rank

4.6

4.2

4.0

3.4

3.4

3.2

2.9

2.5

2.5

2.4

2.1

Source: Lisa Lynch and Robert Zemsky, "EQW National Employers Survey: First Results", EQW mimeo, February 1995

*These data come from the answer to the following question: When you consider hiring a new non-supervisory or production worker (front line worker), how important are the following in your decision to hire? 
Figure 1 Percent of Establishments Engaged in each Type of Training

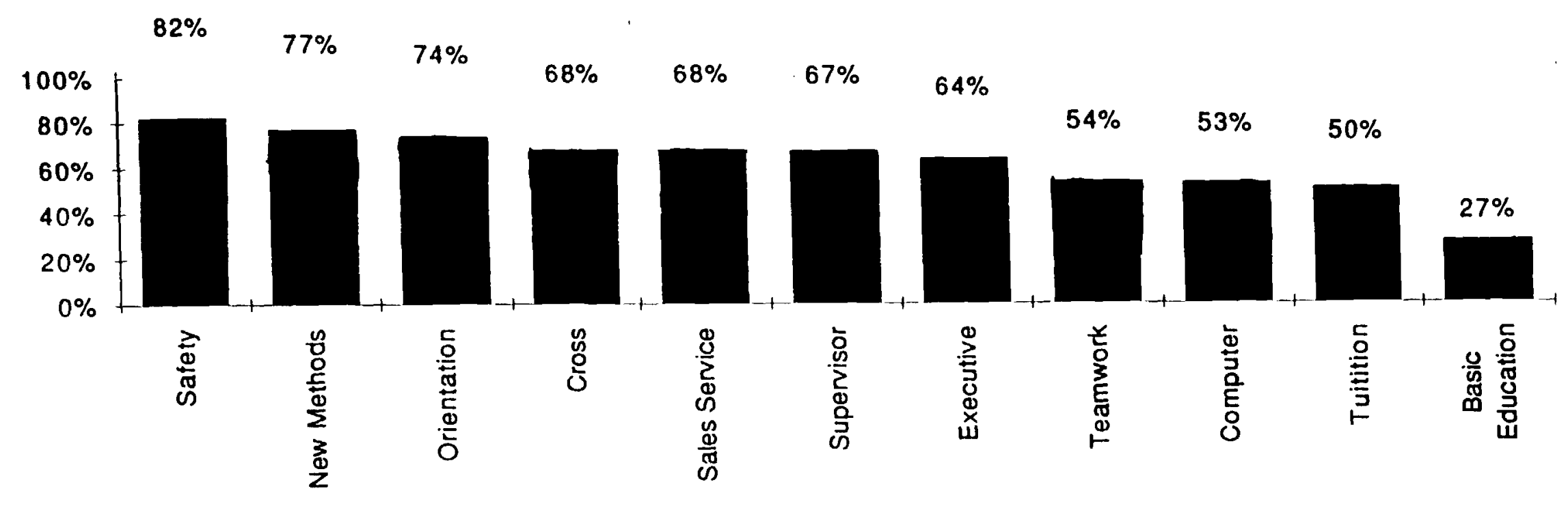




\section{APPENDIX A}

\section{EQW NATIONAL EMPLOYERS SURVEY}

Response Rates ${ }^{1}$

Manufacturing Sector

Completed + All Partials ${ }^{2}$

Completed + Workplace Partials

Completed Interviews
Percent

$75.0 \%$

$70.4 \%$

$66.0 \%$

$69.4 \%$

$66.2 \%$

$60.6 \%$
Number of Cases

1,831

1,728

1,621

\section{Non-Manufacturing Sector}

Completed + All Partials

Completed + Workplace Partials

Completed Interviews

1,516

1,445

1,324

' Empirical analysis of the determinants of the probability of refusing to participate in the survey showed no significant impact of establishment size or industry on the probability of responding for the non-manufacturing sector. For manufacturing, establishments in the largest size category (1000 employees or more) were slightly more likely to refuse to participate in the survey than establishments in all other size categories.

${ }^{2}$ Since all interviews had to be completed by the end of September 1994 some of the survey were not totally completed. The survey was divided into two main sections (and allowed for multiple respondents) - the first on establishments sales and financial information, and the second on employment practices. The bulk of the survey questions were contained in the employment practices section of the survey. Therefore, the final sample includes some partial interviews. Our analysis focuses on the completed plus workplace partials interviews. 


\section{APPENDIX B}

Distribution of Sample by Industry

Establishment Industry

Unweighted

Weighted

\section{Manufacturing}

Food and Tobacco (SIC 20, 21)

Textile and Apparel (SIC 22, 23)

Lumber and Paper (SIC 24, 26)

Printing and publishing (SIC 27)

Chemicals and Petroleum (SIC 28, 29)

Primary Metals (33)

Fabricated metals (34)

Machinery \& Computers, Electrical Machinery, and Instruments (SIC 35, 36, 38)

Transportation Equipment (SIC 37)

Miscellaneous Manufacturing (SIC 25, 30, 31, 32, 39)

$\begin{array}{ll}5 \% & 2 \% \\ 4 \% & 2 \% \\ 6 \% & 2 \% \\ 5 \% & 2 \% \\ 6 \% & 1 \% \\ 6 \% & 2 \% \\ 5 \% & 2 \% \\ & \\ 6 \% & 4 \% \\ 6 \% & 1 \% \\ 6 \% & 6 \%\end{array}$

\section{Non-Manufacturing}

Construction (SIC 15-17)

Transportation Services (SIC 42, 45)

$5 \%$

$7 \%$

Communication (SIC 48)

$2 \%$

$2 \%$

Utilities (SIC 49)

Wholesale Trade (SIC 50, 51)

Retail Trade (SIC 52-59)

$4 \%$

$1 \%$

$5 \%$

$11 \%$

Finance (SIC 60-62)

Insurance (SIC 63, 64)

Hotels (SIC 70)

Business Services (SIC 73)

Total unweighted observations $=3,173$ 


\section{APPENDIX C}

Distribution of Sample by Establishment Size

$\begin{array}{lcc}\text { Establishment Employment } & \text { Unweighted } & \text { Weighted } \\ 20-49 \text { employees } & 16 \% & 53 \% \\ 50-99 \text { employees } & 17 \% & 23 \% \\ 100-249 \text { employees } & 20 \% & 14 \% \\ 250-999 \text { employees } & 30 \% & 8 \% \\ 1000 \text { or more employees } & 17 \% & 2 \% \\ \text { Total unweighted observations } & =3,173 & \end{array}$




\section{APPENDIX D}

Selected Mean Values for Tables 7 and 8 (Unweighted)

Manufacturing Non-manufacturing

Variable Names

Multi establishment

$65 \%$

$61 \%$

Average Education

12.5 years

13 years

$\%$ employees with tenure $<1 \mathrm{yr}$

$12 \%$

$19 \%$

unionized

$35 \%$

$22 \%$

proportion trained 1993

$49 \%$

$47 \%$

\% formal training outside working

$28 \%$

$28 \%$

hours

provide computer training

$78 \%$

$68 \%$

provided teamwork training

$67 \%$

$56 \%$

provided supervisor training

$83 \%$

$75 \%$

grades priority in recruitment

$19 \%$

$15 \%$

communication skills priority in

$68 \%$

$79 \%$

recruitment

above capacity

$7 \%$

$9 \%$

below capacity

$37 \%$

$39 \%$

use benchmarks

$38 \%$

$31 \%$

use total quality management

$56 \%$

$33 \%$

export

$63 \%$

$19 \%$

have $R \& D$ center

$62 \%$

$23 \%$ 